\title{
Human Rights Violation and the Dalits: A Theoretical Background with Special Reference to Odisha
}

\author{
Artatrana Gochhayat \\ Assistant Professor of Political Science, Sree Chaitanya College, Habra,West Bengal,India
}

\begin{abstract}
Human rights violation has become a worldwide phenomenon and is increasing day by day in developing countries like India. Not a single day passes without papers reporting on violation of human rights in India. The vulnerable sections like dalits, adivasis, women, children, minorities and other groups are discriminated without any fault of their own. In this paper, an attempt has been made to highlight on the theoretical analysis of the violation of human rights of Dalits particularly in Odisha. But how the human rights of such Dalit people are being violated despite extensive constitutional and legal protections against such violations? This is the chief objective of this paper.
\end{abstract}

\section{INTRODUCTION}

The history of human rights is a history of people's struggles for liberty and for enforcement of fundamental rights. ${ }^{I}$ In every sphere of life, in country after country, these rights are being violated. Each violation of human rights, wherever it occurs is a great threat to the welfare and dignity of the human civilization. ${ }^{2}$ At every stage of history, voices of poorest against oppression have been heard; in every age, visions of human liberation have also been eclipsed. As we moved towards modern times, these violations have been translated into programmes of social action and at times incorporated into the constitution of States. Yet conflicts, wars and despotic regimes have periodically crushed the very foundation of rights acquired across the centuries, or replaced old conceptions with new approaches to rights. ${ }^{3}$

Human rights can be defined as those rights, which are inherent in human nature and without which human beings can not live with dignity as human beings. Such rights are vested in people and are not granted by Government. Democracy, free and fair media, independent and universal judiciary facilitate the impartial implementation of these rights. The Universal Declaration of Human Rights (UDHR) 1948 was a milestone in judicial and human history. The International Human Rights Conference in Tehran (1969) called by the General Assembly of the United Nations to mark the International Year of Human Rights, came out with a proclamation : "since human rights and fundamental freedom are indivisible, the full realization of civil and political rights without the enjoyment of economic, social and cultural rights is impossible".

It is necessary to emphasize those civil-political rights and economic-social rights are intimately related. There is no inherent conflict between them. The doctrine that repression of basic human freedom is necessary for fulfilling of socio-economic rights and that one must be sacrificed to the other is a pernicious doctrine, propagated by those who desire despotic power over fellow human beings. Ideally speaking, both these sets of rights are complementary to each other, neither being superior nor subordinate to the other. Together they form the core of the essential human rights inherent in every human being.

\section{WHO ARE THE DALITS?}

Dalits, literally meaning "broken people" or "oppressed" in Hindi, are the lowest members of the Hindu caste system in India. The caste system is a Hindu hierarchical class structure with roots in India dating back thousands of years. In descending order, the caste system is considered of Brahmins (priests), Kshyatriyas (warriors), Vaisyas (farmers), Shudras (laborer-artisans), and the Dalits, who are considered so polluted they are beyond caste. Traditionally, caste, determined by birth, defined whom one could marry and the occupation one could pursue. ${ }^{4}$

Dalits are known by different names. Mahatma Gandhi called them Harijan, the children of God. Religious books of the Hindus called them Sudras; Ambedkar called them "depressed classes". However since 1970 the term 'Dalit' has been widely used. Dalit is a Marathi word first used by Mahatma Jotiba Phule, a $19^{\text {th }}$ century social reformer who led a movement for the upliftment of untouchables, which means "broken people". The Government of India officially calls them "Scheduled Castes". 'Scheduled' means they are on a government schedule that entitles them to certain protections and affirmative action (Prasad, 2001). ${ }^{5}$ In Indian languages, the term 'Dalit' literally means 'downtrodden' and conveys the sense of an oppressed people. The Dalit Panthers, a radical group that emerged in western India, used the term to assert their identity as part of their struggle for rights and dignity. Over time, it has emerged as a political category associated with an 
ideology that advocates social transformation in the direction of an egalitarian, just and humane social order. It is an ideology advocating fundamental change in the social structures and relationships among individuals. ${ }^{6}$ According to Gangadhar Patawane, a Dalit writer, "Dalit is not a caste. Dalit is a symbol of change and revolution. A Dalit believes in humanism. He rejects existence of God, rebirth, soul, sacred books that teach discrimination, faith and heaven because these have made him a slave. He represents the exploited man in his country. ${ }^{7}$ For Gopal Guru (2001), the term does not merely express identity- a sense of who the Dalits are- but it also conveys their aspirations and struggle for 'change and revolution'.

\section{VIOLATION OF HUMAN RIGHTS OF DALITS IN INDIA:}

In India Human Rights organizations and newspapers tell countless stories of Dalits who have been beaten, unlawfully detained, tortured, raped, killed and had their homes burned in caste violence. Human rights violation takes place in the form of women right violation, caste right violation and other types of violations. Rape, assault, molestation, brutal killing, abduction, dowry death are very important violations against Dalit women. Untouchability, ill-treatment, of temple entry, non entry to common places, filing of false case, cheating assault, robbery are some important violations against SC/ST people and terrorism kidnapping, custodial death, poverty, corruption, environmental problems are the other types of violations.

The Dalits (also known as Untouchables, Harijans, or Scheduled Castes) have historically been poor, deprived of basic human rights and treated as social inferiors in India. They still face economic, social, cultural and political discrimination in the name of caste. ${ }^{9}$ Dalits who are officially classified as Scheduled Castes comprise about 167 million as per the 2001 Census held. It accounts for 16.23 percentage of total population of India. ${ }^{10}$.Dalits or Scheduled Castes are one of the marginalized sections of the Indian Society who continue to suffer from utter violation of their human rights even today. What is even more alarming that the occurrence of such exploitation and humiliation goes on unabated despite special provisions in the Indian constitution for their protection and claims of affirmative actions having been taken by the state? As per the constitutional provisions, a number of measures- both protective as well as developmental - have been initiated by the government. ${ }^{I I}$ Although India has made measurable progress in terms of the protections afforded to Dalits since independence, Dalits still suffer invidious discrimination and mistreatment at the hands of upper caste members and law enforcement officials. ${ }^{12}$

The Brahmanical social order was based upon the rigid compartmentalization of the common people into major divisions. The Dalits were placed at the bottom of the social hierarchy.It was the toils, tears and labor of the Dalits that made possible the very existence and continuation of the Brahmanical system. Never recognized as full human beings, they were denied access to material, cultural and spiritual resources. They were also deprived of their dignity, selfhood and rights. Dehumanized and humiliated, their relation with the rest of the society was through their obligations to render all services without any claim on return whatsoever. This traditional order was not merely an ideological construct but an economic and political structure. It articulated and encapsulated an entire system of production that existed over centuries with only minor alterations within its confines. The economical and political realities of inequalities were justified, defied and glorified through religious pronouncements based on the purity- pollution divide. Traditionally, ritualistic compulsion and coercive oppression ensured their compliance in providing virtually free labor for the upper caste land owners. The fact that they had been denied right over land or territory only compounded the matter by making them completely dependent upon the owners and controllers of the of the means of production and livelihood. As is well-known, Dalits have been victims of oppression at the hands of the propertied upper castes and still continue to be so despite the law giving effect to the constitutional provisions to do away with caste atrocities. The socioeconomic condition of Dalits remains unchanged till today and social ostracism still continues. There are subtle, often not so subtle discrimination, denial of public space, the transgression of which brings immediate and often brutal reprisals. Instances like wearing chappals, access to temples, places of worship and eating places can also invite brutal reprisals. Discrimination against Dalits is also political in nature. Often their right to vote is taken away through violent means. ${ }^{13}$

\section{CONSTITUTIONAL PROVISIONS FOR DALITS IN INDIAN CONSTITUTION:}

India is a sovereign, socialist, secular, democratic \& republic. Every attribute of the Republic is bedrocked on human rights - the sovereignty of the people over the entire resources of the nation, the secular liberation which interdicts discrimination against individuals and groups on religious grounds, the socialist harvest of economic, cultural and other rights, and the democratic participation through political and civil rights. There are meaningfully implicit in the system of the Republic and made more explicit in the Preamble and Parts III \& IV which have been called the conscience of the constitution. The core objective of the constitution from the socio-economic aspects of human rights is spelt out in Arts.38 and 39 of the constitution. The various constitutional amendments from the very first down to the last, show a determination of the Indian Parliament to transform the economic order \& establish social justice through state action (C. Ganesh,2001). ${ }^{14}$ The articles 
incorporated in the Indian constitution have the bearing on Human Rights discourse. To name a few - Right to equality (Art. 14-18), Right to Freedom (Art. 19-22), Right against exploitation (Art. 23-24), Right to freedom of Religion (Art. 25-28), cultural and educational rights, protection of interests of Minorities (Art. 29-30), Articles related to reservations to SC \& STs 330,332,335,338,339 \&340 (Jogdand, 2001) ${ }^{15}$

Article 17 of the constitution of India has abolished untouchability and its practice in any form has been strictly forbidden. Later, the Parliament enacted Untouchability (Offences) Act, 1955 to give effect to Art 17. To make it more stringent, the Act was amended in 1976 and was renamed as the Protection of Civil Rights Act, 1955 along with the normal provisions of the Indian Penal Code, had been found to be inadequate in providing safeguards to the scheduled Castes/Scheduled Tribes against several crimes. Thus, yet another Act, known as the Scheduled Caste and Scheduled Tribes (Prevention of Atrocities) Act, 1989 was also passed by the Indian Parliament.

But, today, human rights violation is rampant throughout the world particularly in developing countries including India, in spite of adopting a number of declarations, conventions and covenants. Human rights violation is a term used, when a government or society or individual violates the rights of its citizens or its members or any human being. Government and officials violate rights of individuals especially refugees, victims of war, and persons under police or army custody. Women are subject to all types of discrimination and abuse. Children are discriminated, sexually abused and physically assaulted. The rights of Dalits and tribal people are refused. It is alleged that their properties are taken away and their women and girls are raped, assaulted and ill-treated. There are accusations that 'religious minority peoples' properties are damaged and places of worship are destroyed. They are assaulted, false cases are registered against them and they are discriminated by the religious majority. ${ }^{16}$

According to the report of Human Rights Watch $(1999)^{17}$, 'untouchability' was abolished under India's constitution in 1950, the practice of 'untouchability'-the imposition of social disabilities or persons by reason of their birth in certain castes- remains very much a part of rural India. 'Untouchabbbles 'may not cross the line dividing their part of the village from that occupied by higher castes. They may not use the same wells, visit the same temples, drink from same cups in tea stalls, or lay claim to land that is legally theirs. Dalit children are frequently made to sit in back of the class rooms and communities as a whole are made to perform degrading rituals in the name of caste. Dalits are relegated to the most manual of tasks as manual scavengers, remover of human waste and dead animals, leather workers, street sweepers and cobblers. Dalit children make up the majority of those sold into bondage to pay off debts to upper caste creditors.

Human Rights Watch (2007) ${ }^{18}$ finds out that "discriminatory and cruel, inhuman and degrading treatment of over 165 million people in India has been justified on the basis of caste. Caste is descent-based and hereditary in nature. It is a characteristic determined by one's birth into a particular caste, irrespective of the faith practiced by the individual. Caste denotes a traditional system of rigid social stratification into ranked groups defined by descent and occupation. Caste divisions in India dominate in housing, marriage, employment and general social interactions- divisions that reinforced through the practice and threat of social ostracism, economic boycotts and physical violence."

According to Prime Minister Manmohan Singh's comment on December 27, 2007, 'Dalits have faced a unique discrimination in our society that is fundamentally different from the problems of minority groups in general. The only parallel to the practice of untouchability was Apartheid in South Africa. Untouchability is not just social discrimination. It is a blot on human society. ${ }^{19}$

Ellyn Artis et al. (2003) represent a case study of Gujarat that exemplifies a situation in need of a human rights approach that incorporates economic, social and cultural rights that of Dalits of India. According to them, for centuries, Dalits have been victims of gross human rights violations. This has led to their current low social and status within Indian society. All of this has occurred in a country in which the government has not only signed numerous treaties pledging respect of human rights, but has also incorporated it into its constitution. Thus, India presents an interesting case in which commitment is evident on paper but is not exercised in practice. ${ }^{20}$

According to the report of the Ministry of Social Justice and Empowerment as many as 630 cases of crimes were reported to have been committed against persons belonging to the Dalits community in 1996. As per data from 1981 to 1987, about 508 persons belonging to the Scheduled Castes were murdered, about 2343 hurt, 847 subjected to arson, 754 became victims of physical violence and about 12000 were subjected to other offences, on average annually. ${ }^{21}$

\section{I.P. Desai (1976) examines the practice of untouchablity primarily in two spheres:}

a) The private sphere, which is a custom-governed sphere, and

b) The public sphere, which is a law-governed sphere. As per Desai's study, untouchability is strong in the religious and domestic spheres whereas it is less strong and weakening in the occupational sphere. However, it is not a problem in public sphere. ${ }^{22}$ 
Apart from the above mentioned protective measures there are provisions of reservation and representation ('political reservation in various bodies, reservation in government services, admission to educational institution and several other areas) to member of Scheduled Castes and scheduled Tribes, in order to improve their access and participation in the economic, social and political spheres, which come under the category of promotional or developmental measures. But it is worthwhile to note here that discrimination in private sphere - social or economic - is not covered by such measures. The percentage of the Dalit community literacy $(37.41 \%)$ is for below that of the national average $(52.21 \%)$ in the 1991 Census. Be it private employment, school dropout rates, literacy or health indicators, access to higher education or even government jobs, Dalits are most disadvantageously placed. In view of Dalit's enormous contribution to society in terms of labor, art and culture, their share of the country's resources and riches is disproportionately lower. In view of Dalit's enormous contribution to society in terms of labor, art and culture, their share of the country's resources and riches is disproportionately lower. They are mainly landless and where they won land, it is marginal and usually of low quality as well as non-irrigated. An overwhelming majority (nearly 77\%) of the Dalit's workforce is in the primary or agricultural sector of the economy. The Dalits, due to higher incidence of wage labor associated with high rate of under-employment. Suffer from low income and consumption and a resultant greater level of poverty. They work as agricultural laborer, share croppers and self-cultivators. They do not get work throughout the year and live in vulnerable condition. There are a few agricultural laborers that work on a yearly basis and are attached to one master. Their wages are lower than those earned by casual labors. On the other hand, their jobs are secure and they get prerequisites such as clothing and shelter. ${ }^{23}$

But the unfortunate part is that they are thoroughly exploited as they are at the back and call of the master. Dalits constitute a sizeable number among the bonded laborers as well. Such laborers are bonded against the debt that they incurred for marriage or other day-to-day expenses. The primary or agricultural sector being an unorganized sector, these workers are thoroughly exposed to the worst kinds of violations of their basic human rights. Some of them work for the same master for several years or in certain cases, even for life.

The reports of the National Commission on Scheduled Castes and Scheduled Tribes have every year reflected on increase in the number of crimes against the Scheduled Castes. Most of the Dalit women are the victims of rape by upper castes by usurping their lands, giving them low wages, using them as bonded labor, so on and so forth. For checking this exploitation, a set of comprehensive guidelines covering preventive measures have been formulated and communicated by the central government to the state for necessary action. ${ }^{24}$ In spite of these guidelines the exploitation of Dalits, especially Dalit women, continues to exist in almost all states of the country.

The increase in the number of crimes against the Scheduled Castes recorded by the police is evidence from the fact that as against 180 cases registered with the police in 1955, the number of cases increased to 509 in 1960, to 18,336 in 1991 to 24, 973 in 1993 and to 33,908 in 1994. The highest number of crime against Scheduled Castes are reported in Uttar Pradesh, followed by Rajasthan, Madhya Pradesh, Gujarat, Tamil Nadu, Andhra Pradesh, Bihar, Kerala, Karnataka and Maharashtra. For example, of the total crimes against Scheduled Caste reported in 1994-47.7 percent were reported in Uttar Pradesh, 14.1 percent in Rajasthan, 11 Percent in Madhya Pradesh, 5.7 percent in Gujarat, 4.3 percent in Tamil Nadu, 3.5 percent in Andhra Pradesh and 13.17 percent in other States and Union Territories. Further 13.4 percent of cases were reported as cases of hurt, 44.1 percent as Prevention of Atrocities (SC/ST), 2.9 percent as rape cases and 1.6 percent as murder cases. ${ }^{25}$

The rate of conviction in cases of atrocities against Dalits is very low. According to information provided by the Inspector General of Police (Social Justice and Human Rights), there were 18, 752 cases- 4,445 fresh cases and 14,307 "brought forward" cases - involving SCs before special courts between 2003 and 2009. Of these only 412 ended in conviction, where as there were 3,354 acquittals. In 2009, alone, there were 420 acquittals against 29 convictions; 2,656 cases were pending at the close of the year. Official sources acknowledged the prevalence of injustices such as denial of rights to Dalits to worship in temples, bury or burn their dead in common burial or cremation grounds, denial passage to graveyards; and denial of land, water and promotions. $^{26}$

Yet another category of violations is their disenfranchisement during elections throughout the country. There are cases of their being routinely threatened and beaten by the gundas of the political party and compelled them to vote for certain candidates. Those who run for political office in village councils and municipalities (through seats that have been constitutionally reserved for them) have also been threatened to get them to withdraw from the campaign.

$A C H R$ report reveals the failure of the central government and state level authorities to address societal violence and discrimination faced by religious ethnic minorities, indigenous and tribal peoples and members of the Dalit community. The abuses include the failure of the state to address economic and social grievances. The government has regularly failed to provide adequate public security for these groups and failed to prevent nonstate actors from taking the law into their own hands and allowed the space for armed opposition groups to proliferate. $^{27}$ 
Despite the constitutional guarantees the human rights in India are violated and sometimes suppressed by the state and police. The Universal Declaration of Human Rights (1948) has yet to be realized in real life in India. Exploitation of poor by rich, socio-economic and gender inequalities, acute poverty, violation of rights of the citizens by the state and police, suppression of basic human rights of Dalits, have become day to day affairs in Indian Society.

\section{VIOLATION OF HUMAN RIGHTS OF DALITS IN ODISHA:}

The Dalits constitute $16.53 \%$ of Orissa's population. They continued to face discrimination and other human rights violations $(A C H R, 2009)^{28}$.The number of cases of murder, rape, humiliation and sexual harassment on Dalits is increasing day by day. Neither the state nor the law-enforcing machinery has managed to protect the Dalits from the humiliation and atrocities by the upper caste people. In rural belt of the state, the Dalits are even inferior to animals so far as untouchability is concerned. They are denied access to temples/places of public worship, teashops, hotels, restaurants, drinking water resources, upper case house, denial of barber services, denial of laundry services, denial of services by the dhobi, denial of participation in social ceremonies, denial of access to village meetings, denial of food sharing, denial of cremation and burial grounds, separate seating in schools, separate seating in panchayats, separate seating in Self Help Groups etc. The human rights of Dalits have been violated in the sphere of employment, education, heath, land acquisition and especially in their social, political and economic life. In this context, I have tried to cite some of the facts relating to violation of human rights of Dalits in Odisha.

In Orissa, the situation is very pathetic where some of the villages are not connected with metalled or all weather roads. No school facilities or PHC have been started so far, in many villages. Same holds true of electrification of the villages as also SC bastis/hamlets in the state. Even safe drinking water is not provided in most of the villages leaving no option for the SCs than to use dug well/tank/pond or river for drinking purposes. There is no Post office in many of the villages (NCDHR, 2008). ${ }^{29}$

Members of the barber community at Bhubanpati, a coastal village in Puri district of Orissa, are scared of returning to their houses. Four women were beaten up and another was paraded naked allegedly by a group of upper caste men on September, 19, 1005 because their husbands refused to wash the feet of the groom and guests during marriage ceremonies as per custom. Hadibandhu Barik(57) one of the member of barber community said, "Our children are educated and they are not willing to do the customary job of washing the feet of upper caste men, clear the left-overs after the marriage feast and wash the utensils" (The Hindu, 1 October, 2005). ${ }^{30}$

The National Human Rights Commission has issued a notice to the Kendrapara distict administration for not appointing Dalit women as cooks in schools, for preparing mid-day meals. The notice was served following a complaint by a district Dalit Manch accusing the administration of violating a government order which made it mandatory to appoint Dalit women as cooks in 1420 primary schools in the district. The authorities did not appoint Dalit women, as the practice of untouchability prevail in rural areas and towns of the district (Asian Age.com, 27 December, 2005). ${ }^{31}$

About 100 Dalit activists of the Republican Youth and Students' Front (RYSF) organized a massive demonstration in front of the Collectorate in Kendrapara district and submitted a memorandum to DC Kashinath sahu, demanding security of the people of Dalanta village and arrest of the upper people under the SC/ST Atrocities Act. According to the General Secretary, Kshirod Chandra Patro, they wanted to reject Hinduism as it allowed foul animals to touch but not human beings. They said the religion gave upper castes a legitimate right to humiliate rape and murder the lower castes and for which the RYSf had made a call for embracing Buddhism for liberty, equality and fraternity and to make just a social order (Pioneer, 5 January, 2007). ${ }^{32}$

As a blotch on the face of society, some 50 Dalit families facing ostracism are living like refugees outside their own village for the last seven years in Ganjam district of Orissa. Their plight was related to a violent clash over untouchability at Balichhai village under Aska police station on February 20, 2000. A youth D. Pradip Patro, touched some items at a grocery shop in the village, which was objected to by the shopkeeper (The Hindu, 21 May, 2007). ${ }^{33}$

Rashmita Sethy, a scheduled caste woman, and her family have been barred from using a community tube well near her house after she dared to lodge an FIR against two persons, who abused and assaulted her. Rashmita lives with her two year old daughter in Khandagiri Bari on the outskirts of Bhubaneswar. Despite the arrest of the two culprits, Rashmita continued to be denied access to the tube well in front her house so as to pressure her to withdraw the FIR (The Hindu, 2 July, 2007). ${ }^{34}$

An Orissa panchayat has prevented at least 100 Dalit families from consuming tap water on ground of untouchability.Bileisarda village panchayat in Balangir district has kept pending the pipe water connection to Harijanpada, though eight other wards of the panchayat have been given pipe water connection. "Despite drawing the attention of the district administration, no official has turned up at our village", says a Dalit man, Tulsiram Bag (The Times of India, 13 July, 2007). ${ }^{35}$ 
On 1 August, 2008, a Dalit woman identified as Uma Jagat was forced to eat human excreta at Pholenbas village under boden police station in Nawapara district. According the police, a group of tribal beat her up and made her eat human excreta. The police arrested six persons (The Kalinga Times, 8 August, 2008). ${ }^{36}$

In October, 2008, members of five Dalit families were allegedly beaten up by upper caste people at Nathpur village under the Lingaraj police station on the outskirts of capital Bhubaneswar. The alteration began after the upper caste people objected to Dalits' attempt to fell a tree which they (Dalits) had planted. Tension has been rising since the dalits had refused to perform their 'traditional duty' of inviting the upper caste people to attend their community meetings (The Statesman, 13 October, 2008). ${ }^{37}$

In May-June, 2008, member 10 Dalit families of Osakan village under Naugaon police station in Jagatsinghpur district were denied water from the public tube well, barred from attending community religious function performed at Trinath temple and were denied employment in upper caste lands (The Statesman, 17 June, 2008). ${ }^{38}$

The life of Dalits is increasingly vulnerable in the state of Odisha due to a persistent lack of assured entitlements to augment their existing resource base. Land alienation has deprived them of their land; forest legislation has turned them into encroachers on land they have always been used; and they have also been disproportionately affected by displacement due to mining operations, irrigation projects, wildlife sanctuaries etc. It seems that the Government of Odisha is pursuing an agenda of "Hidden Apartheid" of discrimination against Dalits in its policies and programs. The recent incidents of the 'objectionable' behavior of Mass Education Minister, Mr. Pratap Jena towards Dalit youth at Katarapada of Nischintakoili block in Cuttack district and the ongoing atrocities against the Dalit communities in Katarapada village and the negligence of the duty-bearers have shown the lackadaisical attitudes of state machinery for Dalit communities (Shivaram Vij, 2012). ${ }^{39}$

\section{FACTORS RESPONSIBLE FOR THE ATROCITIES AGAINST DALITS:}

In the light of the above facts we can say that despite extensive constitutional provisions, plans and policies, different safeguards like social, economic, educational and cultural, and service, still Dalits are the victims of discrimination, assault, murder, rape and sexual harassment. This practice continues widespread owing to four fundamental causes like continuing belief in untouchability in society, vulnerable of Dalit community, Dalits are not benefitting from the fruits of growth and willful negligence by state institutions.

According to the study of Rabindra K. Mohanty (1988: 55-56) the emerging factors for the atrocities against the Dalits in rural India are: (i) All Dalits are not equally the victims of caste atrocities. Their traditional low ritual status, along with appalling poverty and political disenfranchisement, are factors which add fuel to the fire. (Ii) The past dependence of Scheduled Castes on their non-untouchable counter parts and the present increasing independence through non-traditional employment, higher education and secular income, create a feeling of hatred and jealousy which later manifest in anger, tensions and atrocities. (iii) The inherent interest of the hectic profit chase by the landowners, prosperous farmers, money lenders, mainly from upper caste and top middle castes, creates ample conditions for these classes to utilize semi-feudal and caste-based modes of exploitation and oppression to accelerate their profit-hunt. The lower castes neither get their due share nor have the potentiality to fight. (iv) The atrocities against the Dalits are not the result of a single cause but are caused by a host of factors such as land disputes, traditional low status, illiteracy, poverty, low wages, unremunerative forced labor, indebtedness, resistance to the upper castes, resistance by Dalits to social boycott, use of public facilities and so on. (v) Special facilities to the Scheduled Caste groups through protective discrimination and subsequent manipulation of those by well-off Scheduled Castes bring a sense of jealousy and rivalry among the upper castes, and when they fail to attack the well-off Scheduled Castes, the deprived sections become the ultimate target of attack. (vi) Police connivance, bribery, loopholes in judiciary, unnecessary delay in legal proceedings, lack of awareness regarding legal provisions and government inaction make the culprit escape from the clutches of law. This increases their confidence further to suppress the Dalits.

Neelima $(2008)^{40}$ has listed four primary causes of atrocities against Dalits: land disputes, lack of civic facilities, untouchability-related crimes and self assertion.

\section{CONCLUSION}

However, on the account of the above discussion, I would like to offer some suggestions which might help to halt the violation of human rights of Dalits. These are: i) conscious raising among the Dalits, ii) abolish 'labelling approach' - change the mindset of the higher castes, iii) implement the legal provisions without any fear or favor, iv) coordination between the central and state governments while working out legal provisions, v) states must be powerful and should not remain as an interventionist agency, vi) penalize the village which observe social boycott against Dalits, vii) punish the people severely who use legal provisions to settle their personal scores, and viii) sensitize the people to the norms and values of the human rights movement. 
Apart from this, there is a need of the involvement of the Non-Governmental Organizations (NGOs) to create awareness among the rural masses regarding the human rights and they should organize the people from village level to state to promote and protect the basic human rights of the people. Whenever, there is state oppression or violation of human rights, such voluntary organizations should come forwarded to fight against the state oppression. These voluntary organizations should organize the "Awareness Camps" at village level, district level and regional level. So, the community participation in the promotion and protection of civil and democratic rights would be possible. The community at large should have a strong base to fight against the exploitation and criminality. Through community action, we can reduce the socio-economic inequalities and exploitation of poor by rich to some extent. This kind of approach may yield good results in the course of time.

\section{REFERENCES}

[1] Waghmare, B.S. (ed.), (2001). Introduction to Human Rights: Problems and Prospects, Delhi: Kalinga Publications, p. 1.

[2] Guha Ray, S. (2001). Human Rights, Democratic Rights and Popular Protest, Kolkata: Progressive Publications, p. 4.

[3] Ishay, M.R. ed., (1997). Introduction to The Human Rights Reader, New York: Routledge, p. xiii.

[4] Hanchinamani, Bina B. (2001). 'Human Rights of Dalits in India' Human Rights Brief, Vol.8, Issue 2, p.18

[5] Prasad, V. (2001). Cataract of Silence: Race on the edge of Indian Thought, paper presented for the United Nations Research Institute for social Development (UNRISD) Conference on Racism and Public Policy, Durban, South Africa

[6] Shah, Ghanshyam et al. (2006).Untouchability in Rural India, New Delhi: Sage Publications, p.22.

[7] Patawane, G. (1974). "Mulyavedh [Perception of values]" cited in Ghanashyam Shah et al. (2006) Untouchability in Rural India, New Delhi: Sage Publications, p.22.

[8] Guru, G. (2001). "The Language of Dalit-Bahujan Political Discourse", in Ghanashyam (ed.), Dalit Identity and Politics, New Delhi: Sage Publications.

[9] Kethineni, S. and G.D. Humiston,(2010). "Dalits, The Oppressed People of India: How are Their Social, Economic and Human Rights Abused?" in War Crimes, Genocide and Crime Against Humanity, Vol.-4, p. 100.

[10] National Campaign on Dalit Human Rights (NCDHR), 2008, New Delh, . 5.

[11] Satapathy, B., 2006. "Human Rights of Marginalised Groups: Dalits, Adivasis, Women, Minorities and Unorganised Workers" in Dr. Tapan Biswal (ed.) Human Rights, Gender and Environment, Biva Books, Pvt. Ltd., New Delhi, p. 141.

[12] Hanchinamani, B.B., 2001. "Human Rights Abuses of Dalits in India” Human Rights Brief, 8(2), 29.

[13] Journal of Dalit Resource Centre (2005). Atrocities on Dalits Untouchability: A Historical Overview, Vak, Mumbai.

[14] Ganesh, C. (2001). "Weaker Sections, Human Rights and Voluntary Action” in B.S. Waghmare (ed.) Human Rights: Problems and Prospects, Delhi: Kalinga Publication, p.202.

[15] Jogdand, P.G. (2001). "Indian Social Reality and the Question of Human Rights of the Dalits: Some Observations" in B.S. Waghmare (ed.) Human Rights: Problems and Prospects, Delhi: Kalinga Publication, p.163.

[16] Kanmony, J.C. (2010). Preface to Human Rights Violation, New Delhi: Mittal Publications.

[17] Human Rights Watch (1999). Broken People: Caste Violence Against India's Untouchables, New York: human Rights watch.

[18] Human Rights Watch and the Centre for Human Rights and Global Justice (2007). Hidden Apartheid: Caste Discrimination Against India's "Untouchables", shadow report to the UN Committee on the Elimination of racial Discrimination, February, vol.19, no.3(c), p.2.

[19] Ibid. p.3.

[20] Artis, E., Doobay, C. \& Lyons, K. (2003). Economic, Social and Cultural Rights for Dalits in India: Case Study on Education in Gujarat, workshop on Human Rights: From Grassroots Courage to International Influence, the Woodrow Wilson School of Public and International Affairs, Princeton, NJ. P.3.

[21] Satapathy op.cit.142.

[22] Desai, I.P. (1976). Untouchability in Rural Gujarat, Bombay: Popular Prakashan.

[23] Satapathy op.cit. 143.

[24] Ganesh op.cit.205.

[25] Doorairaj, D. (2010). "Tamil Nadu: Status of Dalits" Frontline, March 26, pp. 39-40.

[26] Chakma, S. (ed.). (2009). "Preface to Human Right Reports", The Asian Centre for Human Rights, New Delhi, p.iv.

[27] Ibid. 158 .

[28] National Campaign on Dalit Human Rights (NCDHR), (2008). Alternate Report of India, New Delhi, p.25.

[29] The Hindu (2005). "Orissa Villagers Protest Against Inhuman Practice", 1 October, cited in Dalit Atrocities-2005, Human Rights Documentation, Indian Social Institute, New Delhi.

[30] Asian Age.com (2005). "Rights Panel send notice on Dalit Issue", 27 December, cited in Dalit Atrocities-2005.

[31] Pioneer (2007). "Dalits Threaten to Embrace Buddhism", 5 january, cited in Dalit Atrocities-2007.

[32] The Hindu (2007). "Ostracized Dalits Seek Justice", 21 May, cited in Dalit Atrocities-2007.

[33] The Hindu (2007). "Dalit Woman Denied Water" 2 July cited in A Bulletin of Dalit resource Centre, VAK, Mumbai, August 2007.

[34] The Times of India (2007). "Panchayat denies Tap Water to Orissa Dalits" 13 July, cited in A Bulletin of Dalit Resource Centre, VAK, Mumbai.

[35] The Kalinga Times (2008). "Dalit Woman made to eat Human Excreta", 8 August cited in S. Chakma (ed.) Asian Centre for Human Rights (ACHR), India Human Rights Report, 2009.

[36] The Statesman (2008). 'Upper Castes 'beat up' Dalits at Nathpur', 13 October, cited in S.Chakma (ed.) Asian Centre for Human Rights (ACHR), India Human Rights Report, 2009.

[37] The Statesman (2008). "Dalits ostracized by the upper castes in Naugaon" 17 June, cited in S.Chakma (ed.) Asian Centre for Human Rights(ACHR), India Human Rights Report, 2009.

[38] Vij, Shivaram. (2012). "Will Naveen Patnaik wake up to atrocities against Dalits in Odisha" in KAFILA, 25 March.

[39] Neelima, B.N. (2002). "Atrocities on Dalits: Need for Human Rights Education" inR. Thilagraj (ed.) Human Rights and Criminal Justice Administration, New Delhi: APH Publishing. 